\title{
Connecting university mathematics and school mathematics to address Klein's double discontinuity: A case of ring theory
}

\author{
Agnita Siska Pramasdyahsari, Rina Dwi Setyawati, Irkham Ulil Albab ${ }^{1}$
}

\begin{abstract}
Abstrak: Artikel ini bertujuan mengungkap bagaimana calon guru matematika mengidentifikasi koneksi antara teori Ring dengan topik matematika sekolah di Indonesia. Data dikumpulkan dari hasil kerja kelompok siswa sebagai bagian tugas mata kuliah teori Ring pada semester 6. Melalui pendekatan deskriptif kualitatif, koneksi matematika yang diidentifikasi oleh calon guru dianalisis menggunakan kerangka kerja konsep-dengan-konsep. Temuan penelitian menunjukkan bahwa koneksi yang dihasilkan calon guru merupakan kategori perbandingan konsep-dengan-konsep yang masih bersifat umum. Calon guru bisa mengelaborasi beberapa koneksi topik matematika secara eksplisit dan menghubungkan ide matematika dari teori Ring terhadap topik matematika sekolah walaupun belum mengungkap semua koneksi yang ada. Untuk pendidik calon guru matematika yang mengajar aljabar lanjut, hasil penelitian ini bisa menjadi panduan untuk merancang (mata) kuliah yang memungkinkan calon guru lebih sadar terkait koneksi matematika yang akan memberikan manfaat untuk peran mereka sebagai guru matematika.
\end{abstract}

Kata kunci: Koneksi matematika, Calon guru matematika, Teori Ring, Matematika sekolah

\begin{abstract}
The article aims to reveal how pre-service mathematics teachers (PMTs) identify the connection between ring theory and the mathematics topics in secondary schools in Indonesia. The data was collected from the students' workgroup as a part of course assignments in ring theory course in $6^{\text {th }}$ semester. Through a descriptive qualitative approach, the identified mathematical connections by the PMTs were analyzed through the concept-by-concept framework. The findings show that connection that PMTs made is categorized as concept-by-concept comparison through common features. They could elaborate on the connected topic explicitly at some points and connect the mathematical ideas from ring theory to the school mathematics topics even though they do not reveal all the existing connections. For mathematics educators who teach advanced algebra, the finding could be a reference for designing a course that enables PMTs to be more aware of the mathematical connections which will be beneficial for their future roles as mathematics teachers.
\end{abstract}

Keywords: Mathematical connections, Pre-service mathematics teachers, Ring theory, School mathematics

\section{A. Introduction}

Mathematics teacher education programs in several Teachers Training Institutions (LPTK) in Indonesia offer the students who will become secondary mathematics teachers with advanced mathematics courses such as abstract algebra (group theory and ring theory). Dubinsky et al. (1994) argue that abstract algebra contributes to mathematics knowledge for teaching by

\footnotetext{
${ }^{1}$ Department of Mathematics Education Universitas PGRI Semarang, Jln. Sidodadi Timur No. 24 Semarang 50232, Indonesia, agnitasiska@upgris.ac.id
} 
providing PMTs with an opportunity to understand how numbers system is structured. Abstract algebra also supports PMTs to develop concept images and concept definitions (Tall \& Vinner, 1981) that help them to explain the concepts in school mathematics. Moreover, undergraduate students learn the terminology and methodology of algebra through abstract algebra (Gallian, 1990). The terminology such as the inverse and identity element, which become part of abstract algebra content, are important for PMTs to strengthen and broaden their understanding of mathematics that they will teach (Findell, 2001). Murray et al. (2017) identified the importance of abstract algebra for secondary mathematics teachers, namely connecting the approaches, content, and principles to communicate mathematics with their students about the relevance of mathematics. For example, abstract algebra can help secondary mathematics teachers explain commutative properties without using strict procedural language.

Notwithstanding the importance of abstract algebra, our observations prior to the present study show that PMTs were struggling to understand and connect the topic to secondary mathematics. Similarly, secondary mathematics teachers often do not understand the mathematics they need to use and teach in schools (Even, 1993). Zazkis and Leikin (2010) found that teachers cannot always clearly articulate how their advanced mathematical knowledge acquired from university mathematics can be used in their school teaching. Furthermore, this knowledge seems irrelevant, and the teachers consider it is useless to obtain such knowledge because of the disconnection between university and school mathematics curriculum (Goulding, Hatch, \& Rood, 2003). However, several connections to teaching school mathematics from abstract algebra (group and isomorphism) have been identified such as the uniqueness of solution in a linear equation is connected to the group properties (Usiskin, 1975a; Usiskin, 1975b; Wasserman, 2016), but the PMTs do not realize that connections.

Several studies focused on the connection between abstract algebra and school mathematics content (e.g., Cofer, 2015; Novotna \& Hoch, 2008; Stockton \& Wasserman, 2014; Suominen, 2015; Wasserman, 2014, 2016; Wasserman \& Stockton, 2013). These studies contribute to informing the research communities the teaching topics from the ideas of abstract algebra that support particular topics in school mathematics and how to integrate abstract algebra into practice. However, most of the prior studies show the mathematical connections between abstract algebra in general and school mathematics teaching without a direct connection from both level or vice versa. For instance, Wasserman (2016) identified the specific topics which connect abstract algebra to the teaching of arithmetic properties, inverses, the structure of sets, and solving equations. It attempted to address the second part of Klein's $(1932 ; 2016)$ double discontinuity that abstract algebra could be related to school mathematics teaching, but did not show the specific connection of concepts from both levels. Therefore, the present study intended to emphasizes the mathematical connections as a concept-by-concept (Zazkis, 2000). Conceptby-concept connection is defined as a direct connection from the concepts in ring theory to build another concept in school mathematics or vice versa. For instance, the use of ring properties $a^{m} \cdot a^{n}=a^{m+n}$ could directly support the school mathematics teachers in explaining the concept of the exponent.

By considering the importance of mathematical connection which improve the mathematical understanding (NCTM, 2000), it is essential to address Klein's $(1932 ; 2016)$ double discontinuity. Klein $(1932 ; 2016)$ conceptualised the notion of the double discontinuity curriculum between university mathematics and school mathematics which impact on the teaching practices. The first discontinuity is that the university mathematics curriculum offers 
the ring theory course. However, it does not develop from the knowledge that students (preservice teachers) already have from school mathematics. For example, when the lecturer explains the inverse and identity element in an abstract algebra course, the explanation can be developed from an inverse function that students have already known from school mathematics. The second discontinuity is that when teachers teach school mathematics, ring theory does not relate to their teaching. For instance, teachers might not be explicitly aware of using the knowledge of ring theory to explain secondary mathematics topics such as inverse function.

The present study attempted to address Klein's double discontinuity and focused on the specific connection between the university and school mathematics. Specifically, it aimed to reveal how PMTs identify the mathematical connection between ring theory and school mathematics. This study contributes to the understanding of how PMTs connect university mathematics topics to school mathematics. It can be utilized to design a course or revise the current courses in mathematics teacher education program (LPTK) which equip the future mathematics teachers a connected knowledge.

\section{B. Methods}

The current study employed a descriptive qualitative approach (Creswell \& Creswell, 2014). Data were collected from 30 PMTs who enrolled in ring theory course in one LPTK located in central Java. A course assignment was given to identify the mathematical connection between the ring theory and mathematics topics in secondary school mathematics (junior and senior high school). The procedures of the study were: Firstly, in the initial course meeting, the subjects were randomly divided into six groups. Secondly, each group identified and listed the major content in the ring theory at every meeting for 14 lessons. Thirdly, they also identified the school mathematics topics based on the syllabus document within the 14-course meeting. Fourthly, they drew a concept-by-concept connection between ring theory and school mathematics topics. The concept-by-concept connection of each group is presented in Table $2-$ Table 7.

Data were analyzed in three steps: data condensation, data display, and drawing conclusion (Miles, Huberman, \& Saldana, 2013). In the data condensation stage, the subjects' works were firstly classified based on their group then reduced into the connected topics. In the data display, the list of connected topics was presented into the table then analyzed descriptively whether or not fulfil the category of concept-by-concept connection (Zazkis, 2000). Afterwards, identified concept-by-concept connections of ring theory and school mathematics topics were examined through categorization of mathematical connections (Suominen, 2015) as in Table 1. In the last stage, the connections of ring theory and school mathematics topics identified by PMTs were concluded.

Table 1. The categorization of mathematical connection (Suominen, 2015)

\begin{tabular}{ll}
\hline \multicolumn{1}{c}{ Category } & \multicolumn{1}{c}{ Description } \\
\hline Alternative representation & One concept is represented in different ways \\
& such as symbolic (algebraic), graphic \\
(geometric), and pictorial (diagram), & manipulative (physical object), verbal \\
& description (spoken), or written description). \\
& Two concepts share some features in common, \\
Comparison through common features & which allow a comparison through the \\
\hline
\end{tabular}




\begin{tabular}{ll}
\hline \multicolumn{1}{c}{ Category } & \multicolumn{1}{c}{ Description } \\
\hline Equivalent representation & $\begin{array}{l}\text { concepts being similar, exactly the same or not } \\
\text { the same. } \\
\text { One concept is represented in different ways } \\
\text { but within the same form (one concept could } \\
\text { be represented in different ways symbolically). }\end{array}$ \\
One concept is an example of a specific \\
instance of another concept. \\
One concept is a component of or included in \\
another concept. Since one concept is included \\
or contained in the other concept, a \\
hierarchical relationship exists between two \\
concepts. \\
One concept logically dependences on another \\
concept. Often an if-then relationship exists \\
between two concepts. \\
One concept can be used to find another \\
concept. \\
Procedural \\
Real-world application \\
(a concept refers to another concept outside the \\
current mathematical concept).
\end{tabular}

\section{Findings and Discussion}

This part firstly presents students' identified connection in a table following by its interpretations. The results are compiled in a table, and the referred findings are drawn. Then, we discuss the findings and its implication for mathematics teacher education. Table 2 - Table 7 show students' worked connections in each group.

Table 2. Students' work on group 1

\begin{tabular}{|c|c|c|}
\hline Ring Theory & School Mathematics & School Level \\
\hline $\begin{array}{l}\text { Abelian Group (closed, associativity, } \\
\text { identity, inverses and commutative) }\end{array}$ & Numbers operation and properties & $\begin{array}{l}\text { Junior high school } \\
\text { grade } 7\end{array}$ \\
\hline $\begin{array}{l}\text { Ring Properties: } a^{m} \cdot a^{n}=a^{m+n} \text { and } \\
\left(a^{m}\right)^{n}=a^{m n}\end{array}$ & Properties of exponent numbers & $\begin{array}{l}\text { Junior high school } \\
\text { grade } 11\end{array}$ \\
\hline $\begin{array}{l}\boldsymbol{a} \in \mathbb{R} \ni \boldsymbol{a}^{2}=\boldsymbol{a} \rightarrow \boldsymbol{a} \text { is an } \\
\text { idempotent }\end{array}$ & $\begin{array}{l}\text { Sets, } A \cup A=A \text { and } \quad A \cap A=A \\
\text { It is called as idempotent property }\end{array}$ & $\begin{array}{l}\text { Junior high school } \\
\text { grade } 8\end{array}$ \\
\hline $\begin{array}{l}\text { Ring without zero divider: } \boldsymbol{a} \neq \\
\mathbf{0} \text { and } \boldsymbol{b} \neq \mathbf{0} \Rightarrow \boldsymbol{a} . \boldsymbol{b} \neq \mathbf{0}\end{array}$ & $\begin{array}{l}\text { Multiplication of fractions } \\
\text { For any fractions } \frac{c}{a} \text { dan } \frac{d}{b}, a \neq\end{array}$ & $\begin{array}{l}\text { Junior high school } \\
\text { grade } 7\end{array}$ \\
\hline $\begin{array}{l}\text { Supposed }(\mathrm{R},+, \mathrm{x}) \text { and }(\mathrm{S},+, \mathrm{x}) \text { are } \\
\text { Ring, } \boldsymbol{\phi}: \boldsymbol{R} \rightarrow \boldsymbol{S} \text { ring } \\
\text { homeomorphism, if and only if } \\
\forall \boldsymbol{x}, \boldsymbol{y} \in \boldsymbol{R}:(\mathrm{i}) \boldsymbol{\phi}(\boldsymbol{x}+\boldsymbol{y})=\boldsymbol{\phi} \boldsymbol{x}+\boldsymbol{\phi} \boldsymbol{y} \\
\text { (ii) } \boldsymbol{\phi}(\boldsymbol{x} \boldsymbol{y})=(\boldsymbol{\phi} \boldsymbol{x})(\boldsymbol{\phi} \boldsymbol{y})\end{array}$ & $\begin{array}{l}0 \text { dan } b \neq 0 \Rightarrow a b \neq 0 \\
\text { Relation and function } \\
\text { Algebraic operation }\end{array}$ & $\begin{array}{l}\text { Senior high school } \\
\text { grade } 11\end{array}$ \\
\hline Monomorphism & Relation and function & $\begin{array}{l}\text { Junior high school } \\
\text { grade } 8\end{array}$ \\
\hline Integral domain & Algebraic operation & $\begin{array}{l}\text { Junior high school } \\
\text { grade } 7\end{array}$ \\
\hline Ring division & Multiplication of inverses matrix & $\begin{array}{l}\text { Senior high school } \\
\text { grade } 11\end{array}$ \\
\hline
\end{tabular}




\begin{tabular}{lll}
\hline \multicolumn{1}{c}{ Ring Theory } & \multicolumn{1}{c}{ School Mathematics } & \multicolumn{1}{c}{ School Level } \\
\hline Definition ring & Subset & $\begin{array}{l}\text { Junior high school } \\
\text { grade } 7\end{array}$ \\
Ideal & Binary operation & $\begin{array}{l}\text { Junior high school } \\
\text { grade } 7\end{array}$ \\
Ring homomorphism & Relation and function & $\begin{array}{l}\text { Junior high school } \\
\text { grade 8 }\end{array}$ \\
\hline
\end{tabular}

Table 2 shows that group 1 could identify concept-by-concept connection from ring theory which is connected to the number operations, sets, multiplication of fraction, properties of exponents numbers, relation and function, and algebraic function. These concepts are recognized as the concept-by-concept connection based on the classification from the previous studies (Usiskin, 1975a, 1975b; Suominen, 2015). One of the specific connections from Table 2, for instance, ring properties $a^{m} \cdot a^{n}=a^{m+n}$ and $\left(a^{m}\right)^{n}=a^{m n}$ could be developed from the knowledge of exponents properties learnt from school mathematics. However, other connections such as the integral domain, ring division, definition ring, ideal, and ring homomorphism do not include in the category of concept-by-concept because these concepts are not directly interrelated to the chosen school mathematics concepts in Table 2.

Table 3. Students' work on group 2

\begin{tabular}{lll}
\hline \multicolumn{1}{c}{ Ring Theory } & \multicolumn{1}{c}{ School Mathematics } & \multicolumn{1}{c}{ School Level } \\
\hline $\begin{array}{l}\text { Ring properties (associativity, } \\
\text { commutative, and distributive) }\end{array}$ & Number operations & Junior high school \\
Inverse & & \\
Idempotent and nilpotent element & Functions & Senior high school \\
Commutative ring & Multiplication & Junior high school \\
Ideal & Subset and number operation & Junior high school \\
Ring homomorphism & Number operation & Junior high school \\
& & \\
\hline
\end{tabular}

Table 3 shows that group 2 could identify the connections from ring theory to school mathematics, such as number operations, functions, and sets that fulfil the concept-by-concept connections. These correct connections are quite limited both in numbers of connections and the way to present the specific concept that match. The group only determine the concept from ring theory without presenting a particular concept that intends to connect. However, it has been fulfilled the categorization of concept-by concept connection. Other concepts listed from ring theory such as commutative ring, ideal, ring homomorphism are not suitable to the concept-byconcept connection to the school mathematics since these concepts do not match each other. For example, the ring concept about ideal does not specifically relate to the concept of subset and number operation at school mathematics. Moreover, the students in this group only identified the school level without class information.

Table 4. Students' work on group 3

\begin{tabular}{|c|c|c|}
\hline Ring Theory & School Mathematics & School Level \\
\hline Ring & $\begin{array}{l}\text { Numbers operation, } \\
\text { Algebraic operation and } \\
\text { Algebraic properties }\end{array}$ & Junior high school grade 8 \\
\hline $\begin{array}{l}\boldsymbol{a} \in \mathbb{R} \ni \boldsymbol{a}^{\mathbf{2}}=\boldsymbol{a} \rightarrow \boldsymbol{a} \text { is an } \\
\text { idempotent element }\end{array}$ & Sets & Junior high school grade 7 \\
\hline
\end{tabular}




\begin{tabular}{ll}
\hline $\mathbf{b} \in \mathbb{R}, \exists \mathbf{n} \in \mathbf{B}^{+} \ni \mathbf{b}^{\mathbf{n}}=\mathbf{0} \rightarrow$ & For any set $\mathrm{A}, A \cup A=A$ and \\
$\mathbf{b}$ is a nilpotent element & $A \cap A=A$, it is idempotent \\
& properties. \\
Ring homomorphism & Composition function \\
Sub ring & Set and composition function $\quad$ Junior high school grade 8 \\
\hline
\end{tabular}

Table 4 reveals that group 3 only provided a limited connection from ring theory to school mathematics, which fulfil the concept-by-concept connections. However, the concepts from ring theory were presented in detail to connect the concepts from school mathematics. The concepts from ring theory that satisfy the concept-by-concept connection are ring, idempotent element, and nilpotent element which consecutively relate to the concept of numbers operation, algebraic operation, and algebraic properties in school mathematics. Another connection that was made such as ring homomorphism and subring cannot be categorized as a concept-by-concept connection because these concepts do not have a specific link or the similar idea to build the concept of composition function and set.

Table 5. Students' work on group 4

\begin{tabular}{ll}
\hline \multicolumn{1}{c}{ Ring Theory } & \multicolumn{1}{c}{$\begin{array}{c}\text { School Mathematics } \\
\text { (Junior and Senior High School) }\end{array}$} \\
\hline Ring & Numbers operation \\
Ring Properties & Algebraic properties \\
Inverse & Inverse \\
Monomorphism, epimorphism, and isomorphism & Function \\
Commutative Ring & Commutative in multiplication \\
Factor Ring & Number operation \\
\hline
\end{tabular}

Table 5 presents the works of group 4 that only identified the topics on ring theory and school mathematics without presenting the specific classroom level. There are four identified connections which fulfil the concept-by-concept connection, namely function, numbers operation, algebraic properties, and inverse. Meanwhile, there are two concepts such as commutative ring and factor ring which is not properly matched to the concept by concept connection since these concepts do not specifically build the basic concept for commutative in multiplication and numbers operations in school mathematics.

Table 6. Students' work on group 5

\begin{tabular}{|c|c|c|}
\hline Ring Theory & School Mathematics & School Level \\
\hline $\begin{array}{l}\boldsymbol{a} \in \mathbb{R} \ni \boldsymbol{a}^{2}=\boldsymbol{a} \rightarrow \boldsymbol{a} \text { is } a n \\
\text { idempotent element }\end{array}$ & $\begin{array}{l}\text { Sets, } A \cup A=A \text { and } A \cap \\
A=A \text { is idempotent } \\
\text { property }\end{array}$ & Junior high school grade 7 \\
\hline $\begin{array}{l}\text { Ring Properties: } \boldsymbol{a}^{\boldsymbol{m}} \cdot \boldsymbol{a}^{\boldsymbol{n}}=\boldsymbol{a}^{\boldsymbol{m}+\boldsymbol{n}} \\
\text { and }\left(\boldsymbol{a}^{\boldsymbol{m}}\right)^{\boldsymbol{n}}=\boldsymbol{a}^{\boldsymbol{m} \boldsymbol{n}}\end{array}$ & $\begin{array}{l}\text { Properties of exponent } \\
\text { numbers }\end{array}$ & Senior high school grade 10 \\
\hline$\forall \boldsymbol{a} \in \mathrm{R}, \exists \boldsymbol{u}=$ unit, a.u $=$ u.a $=\mathrm{a}$ & Identity Matrix & Senior high school grade 11 \\
\hline $\begin{array}{c}\emptyset(\boldsymbol{m}+\boldsymbol{n})=(\boldsymbol{m}+\boldsymbol{n}) \boldsymbol{u}= \\
\boldsymbol{u}+\boldsymbol{u}+\cdots+\boldsymbol{u}[(\boldsymbol{m}+\boldsymbol{n}) \text { times }] \\
=\end{array}$ & $\begin{array}{l}\text { Numbers properties } \\
\text { (distributive) }\end{array}$ & Junior high school grade 7 \\
\hline
\end{tabular}




\begin{tabular}{|c|c|c|}
\hline Ring Theory & School Mathematics & School Level \\
\hline $\begin{array}{r}(\boldsymbol{u}+\boldsymbol{u}+\cdots+\boldsymbol{u})(\boldsymbol{m} \text { times }) \\
+(\boldsymbol{u}+\boldsymbol{u}+\cdots \\
+\boldsymbol{u})(\mathrm{n} \text { times })\end{array}$ & & \\
\hline $\begin{array}{l}=\boldsymbol{m u}+\boldsymbol{n u} \\
\boldsymbol{a} \in \boldsymbol{R} \ni \boldsymbol{a}^{2}=\boldsymbol{a} \text { is idempotent } \\
\boldsymbol{b} \in \boldsymbol{R}, \exists \boldsymbol{n} \in \boldsymbol{B}^{+} \ni \boldsymbol{b}^{\boldsymbol{n}}=\mathbf{0} \text { is } \\
\text { nilpotent }\end{array}$ & $\begin{array}{l}\text { Idempotent, Periodic, and } \\
\text { Nilpotent Matrix }\end{array}$ & Senior high school grade 11 \\
\hline Ring Homomorphism & $\begin{array}{l}\text { Relation and Function } \\
\text { Algebraic operation }\end{array}$ & Senior high school grade 11 \\
\hline Monomorphism & Relation and Function & Junior high school grade 8 \\
\hline Subring & Set & Junior high school grade 7 \\
\hline Ideal & Subset & Junior high school grade 7 \\
\hline Ideal Maximum & Prime Numbers & Junior high school grade 7 \\
\hline Definition Ring & Binary Operation & Junior high school grade 7 \\
\hline
\end{tabular}

Group 5, as shown in Table 6, could identify into details several concept-by-concept connections from ring theory to the school mathematics. The ring theory was connected to the topics of sets, properties of exponent numbers, identity matrix, matrix (idempotent, periodic, nilpotent), relation and function, and algebraic operation. However, others topics such as subring, ideal, ideal maximum, and definition ring do not fulfil the concept-by-concept connection because these concepts do not share the similar idea which connects to the chosen concepts from school mathematics and vice versa.

Table 7. Students' work on group 6

\begin{tabular}{|c|c|c|}
\hline Ring Theory & School Mathematics & School Level \\
\hline Ring definition and axioms & Algebraic properties & Junior high school grade 7 \\
\hline Inverse property & Inverse matrix & Senior high school grade 10 \\
\hline $\begin{array}{l}\text { Ring properties } \boldsymbol{m} \cdot \boldsymbol{a}=\boldsymbol{a}+\boldsymbol{a}+ \\
\boldsymbol{a}+\boldsymbol{a} \ldots+\boldsymbol{a}(m \text { term })\end{array}$ & Number operations & Junior high school grade 7 \\
\hline 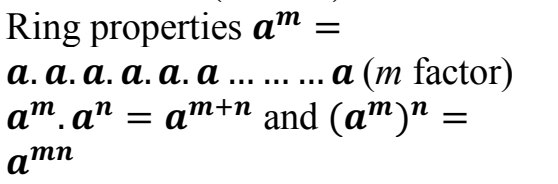 & $\begin{array}{l}\text { Properties of exponent } \\
\text { numbers }\end{array}$ & Junior high school grade 11 \\
\hline $\begin{array}{l}\text { The requirement of integral } \\
\text { domain ring commutative, ring } \\
\text { with the unit, and ring without zero } \\
\text { divisor. }\end{array}$ & $\begin{array}{l}\text { Algebraic properties: } \\
\text { commutative and identity }\end{array}$ & $\begin{array}{l}\text { Junior high school grade } 7 \\
\text { senior high school grade } 10\end{array}$ \\
\hline $\begin{array}{l}\text { Monomorphism, epimorphism, } \\
\text { and isomorphism }\end{array}$ & Relation and function & Senior high school grade 10 \\
\hline Inverses property & Inverses matrix & Senior high school grade 10 \\
\hline Integral Domain & Numbers operations & Junior high school grade 7 \\
\hline Commutative Ring & Set & Junior high school grade 7 \\
\hline Ideal & Numbers operations & Junior high school grade 7 \\
\hline
\end{tabular}

Table 7 presents six connections between ring theory and school mathematics with specific school level. The connected topics from ring theory to school mathematics are algebraic properties, inverse matrix, numbers operations, properties of exponent numbers, and relation and function. Besides these connections, there are four inappropriate connections, namely inverse property, integral domain, commutative ring, and ideal, which is not included in the concept by 
concept connection. These concepts do not properly match the concept-by-concept connection because they do not have a specific similar idea to build the concept to the chosen topics of school mathematics in Table 7.

Referring to Table 2 - Table 7 and its interpretations, the findings of the present study are classified into three general ideas, namely (1) each group has different way to represent the concept-by-concept connections into table; (2) almost all of the groups could identify the common concept-by-concept connection from ring theory to the school mathematics; and (3) limitation to reveal as many as concept-by-concept connections since there are several concepts which do not satisfy the concept-by-concept connection. According to Suominen's (2015), as seen in Table 1, the appropriate connections from the students' group are categorized into concept-by-concept comparison through common features. These three findings will be elaborated into the following paragraph.

Each group has a different approach to present concept-by-concept connections. For several groups as shown in Table 2, Table 4, Table 6 and Table 7, they tried to show the specific concept such as ring properties $m . a=a+a+a+a \ldots+a$ ( $m$ term) connected to numbers operations. This work shows that the group could spot and match the concept-by-concept precisely into details from both levels. They also provide a brief explanation of each concept from both ring theory and school mathematics. It shows that the PMTs know the concept-by-concept connection that they created. For another table, the groups only present the concept without any detailed explanation to the specific idea then connect to the school mathematics concepts.

Moreover, almost all of the groups could identify the common concept-by-concept connection from ring theory to school mathematics. The common concept explicitly appeared from both ring theory and school mathematics is that properties of the ring that connect to the concepts of numbers operation. It discloses that these concepts are easily identified by each group. Therefore, it can be seen that each group present similar concepts to other groups.

The group have limitation to reveal as many as concept-by-concept connections. They only presented the common concepts from ring theory so that the number of connections is limited. Despite these limitations, PMTs still make a link that does not match the concept-by-concept. It can be seen that each group has several concepts from ring theory which do not specifically relate to the concepts in school mathematics listed on the table. These findings agree to Klein's (1932; 2016) double discontinuity: The ring theory taught in university mathematics did not derive from school mathematics concepts and vice versa. Therefore, the PMTs have difficulty in mapping and connecting the concept between them.

Table 8 presents the concept-by-concept connection which is created based on the analysis of syllabi of ring theory and school mathematics in Indonesian context and connect to Suominen's category of mathematical connections (2015) to compare the connection that has been identified by PMTs.

Table 8. Concept-by-concept connections between ring theory and school mathematics

\begin{tabular}{ll}
\hline \multicolumn{1}{c}{ Concepts in ring theory } & Secondary school mathematics concepts \\
\hline Algebraic Structures and Properties & Function and domain \\
& Identity \\
& Inverse \\
& Number systems and operators \\
Binary Operation & Solving linear equations \\
\hline
\end{tabular}




\begin{tabular}{ll}
\hline \multicolumn{1}{c}{ Concepts in ring theory } & Secondary school mathematics concepts \\
\hline & Domain \\
& Function \\
& Function Composition \\
& Function Transformation \\
Commutative Ring theory & Fractions \\
Homomorphism/isomorphism & Equality \\
& Function \\
Ideal & Mapping \\
& Number Systems \\
Inverse & Subsets \\
& Multiplicative reciprocal \\
Kernel & Negative numbers \\
Nilpotent & Null space of a matrix \\
Sign Rule in a Ring & Geometric series \\
Units & Product of two negative numbers is positive \\
Zero Divisors & Invertible Matrix \\
\hline
\end{tabular}

The connections of ring theory and school mathematics in this study do not fully reveal all the connections found on prior studies (Usiskin, 1975a, 1975b; Suominen, 2015). There are several possible reasons that make the students unable to fully identify the connections. Firstly, the lack of teaching experience because PMTs have not had teaching practices in that semester. Even though PMTs had experienced as a student in the school, they might have difficulty in connecting the present concepts in the ring theory course with the school mathematics. Secondly, there is no connection established in the learning process which allows Klein's $(1932 ; 2016)$ double discontinuity that the concepts taught from the school mathematics could not be easily brought to university mathematics, in this case in the ring theory course. Vice versa, the concepts learnt from school mathematics could not explicitly connect to the ring theory. This reason also follows Cook (2012), who assumes that the difficulty in connecting the concept because of the lack of connection between university mathematics and school mathematics. Thirdly, the teaching method of ring theory is full of the proven theorem that encourages the students to think systematically. Fourthly, ring theory seems difficult for most of the PMTs. Therefore, it is essential for the lecturers who teach advanced mathematics in the teacher preparation program to consider the connections to bridge the gap. They need to pay more attention in preparing the teaching resource, which facilitates the PMTs to draw the connections which bridge the university mathematics and school mathematics.

Overall, the findings of this study show that PMTs were able to identify the connection between ring theory and topics in secondary school mathematics with some limitations. By knowing the connections between the ring theory and school mathematics topic or concept, the PMTs will recognize the importance of the course for their future teaching. Even though several concepts are overlap while connected to the concepts in the school mathematics and do not reveal all the connections, refer to the table 8, PMTs realize the existing mathematical connections in several ways by analyzing concept-by-concept that can be seen from table $2-7$.

As the findings reveal how PMTs identified the mathematical connection in some limitations, it could be a suggestion for LPTK to prepare an appropriate curriculum which facilitates the gap between university mathematics and school mathematics. Moreover, the teaching resource which accommodates the need for future teaching is necessary to be prepared. 
These could possibly connect the university mathematics and school mathematics for addressing Klein's double discontinuity. The PMTs will learn the concepts in abstract algebra derived from the school mathematics concept, while they are back to schools for their future teaching the PMT's can connect the fundamental concepts from abstract algebra that support the concepts in school mathematics. Specifically, the findings related to the concept-by-concept connection between ring theory and school mathematics could be a reference for mathematics educators who teach advanced algebra, particularly in abstract algebra to help the pre-service mathematics teachers know and aware of the connection between the university and school algebra. By knowing the connections between the ring theory and school mathematics topic or concept, the PMTs will recognize the important the course for their future teaching. However, the present study only revealed how the PMTs identified the mathematical connection without knowing how they use to solve school mathematics problems. Therefore, further studies are suggested to review how PMTs use these connections into teaching practice. Furthermore, it is also needed to identify another advanced mathematics course taught in the mathematics teacher program that could help to connect Kleins' double discontinuity.

\section{Conclusion}

The present study reveals that the connections of ring theory and school mathematics topics identified by PMTs are still overlapped and limited to the common idea such as connecting ring concept to the number operation. The limitations of PMTs in identifying the mathematical connections might be caused by several possible reasons such as the lack of teaching experience, no developed connection in the learning process which allow the Klein's double discontinuity, the teaching method utilized in ring theory is full of proven theorem that encourages the students to think systematically, and ring theory seems difficult for most of the PMTs. Therefore, to tackle this situation, it is important for the mathematics educators who teach advanced algebra to pay more attention in preparing the teaching resource which facilitates the PMTs to draw the connections which bridge the university mathematics and school mathematics.

\section{References}

Cofer, T. (2015). Mathematical explanatory strategies employed by prospective secondary teachers. International Journal of Research in Undergraduate Mathematics Education, 1(1), 63-90. Doi:10.1007/s40753-015-0007-9

Cook, J. P. (2012). A guided reinvention of ring, integral domain, and field (Doctoral dissertation). Oklahoma: University of Oklahoma. Retrieved from https://search.proquest.com/docview/1031212721

Creswell, J. W., \& Creswell, J. D. (2014). Research design: Qualitative, quantitative, and mixed methods approaches (4th edition). London: Sage publications.

Dubinsky, E., Dautermann, J., Leron, U., \& Zazkis, R. (1994). On learning fundamental concepts of group theory. Educational Studies in Mathematics; an International Journal, 27(3), 267-305. Doi: 10.1007/BF01273732

Even, R. (1993). Subject-matter knowledge and pedagogical content knowledge: prospective secondary teachers and the function concept. Journal for Research in Mathematics Education, 24(2), 94-116. Doi:10.2307/749215

Findell, B., R. (2001). Learning and understanding in abstract algebra (Doctoral dissertation). Durham: University of New Hampshire. Retrieved from https://scholars.unh.edu/cgi/viewcontent.cgi?article=1050\&context=dissertation 
Connecting university mathematics and school mathematics...

Gallian, J. A. (1990). Contemporary abstract algebra (2nd ed.). Lexington, MA: D. C. Heath.

Goulding, M., Hatch, G., \& Rodd, M. (2003). Undergraduate mathematics experience: Its significance in secondary mathematics teacher preparation. Journal of Mathematics Teacher Education, 6(4), 361393. Doi:10.1023/A:1026362813351

Klein, F. (1932). Elementary mathematics from an advanced standpoint: Arithmetic, algebra, analysis (3rd ed., Vol. 1, E. R. Hedrick \& C. A. Noble, Trans.). New York, NY: Macmillan.

Klein, F. (2016). Elementary mathematics from a higher standpoint. Volume 1: Arithmetic, algebra, analysis (G. Schubring, Trans.). Berlin: Springer.

Miles, M.B., Huberman, A.M., \& Saldana, J. (2013). Qualitative data analysis: A methods sourcebook. London: Sage Publication.

Murray, E., Baldinger, E., Wasserman, N., Broderick, S., \& White, D. (2017). Connecting advanced and secondary mathematics. Issues in the Undergraduate Mathematics Preparation of School Teachers, 1. Retrieved from https://digitalcommons.montclair.edu/mathsci-facpubs/4

NCTM. (2000). Principles and standards for school mathematics. Reston, VA: Author.

Novotna, J., \& Hoch, M. (2008). How structure sense for algebraic expressions or equations is related to structure sense for abstract algebra. Mathematics Education Research Journal, 20(2), 93-104. Doi:10.1007/BF03217479

Tall, D. O., \& Vinner, S. (1981). Concept image and concept definition in mathematics with particular reference to limit and continuity. Educational Studies in Mathematics, 12, 151-169. Doi:10.1007/BF00305619

Usiskin, Z. (1975a). Applications of groups and isomorphic groups to topics in the standard curriculum, grades 9-11: Part I. The Mathematics Teacher, 68(2), 99-106.

Usiskin, Z. (1975b). Applications Of Groups And Isomorphic Groups To Topics In The Standard Curriculum, Grades 9-11: Part II. The Mathematics Teacher, 68(3), 235-246.

Stockton, J. C., \& Wasserman, N. H. (2014). The impact of teachers' knowledge of group theory on early algebra teaching practices. Paper presented at Association of Mathematics Teacher Educators (AMTE) Annual Conference 2014. Retrieved from https://www.tc.columbia.edu/faculty/nhw2108/faculty-profile/files/AMTE-presentation.pdf

Suominen, A. L. (2015). Abstract algebra and secondary school mathematics: Identifying and classifying mathematical connections (Doctoral dissertation). Georgia: University of Georgia. Retrieved from https://getd.libs.uga.edu/pdfs/suominen_ashley_1_201505_phd.pdf

Wasserman, N. H. (2014). Introducing algebraic structures through solving equations: Vertical content knowledge for K-12 mathematics teachers. Primus, 24(3), 191-214. Doi:10.1080/10511970.2013.857374

Wasserman, N. H. (2016). Abstract algebra for algebra teaching: Influencing school mathematics instruction. Canadian Journal of Science, Mathematics and Technology Education, 16(1), 28-47. Doi:10.1080/14926156.2015.1093200

Wasserman, N. H., \& Stockton, J. C. (2013). Horizon content knowledge in the work of teaching: A focus on planning. For the Learning of Mathematics, 33(3), 20-23.

Zazkis, R. (2000). Factors, divisors, and multiples: Exploring the web of students' connections. CBMS Issues in Mathematics Education, 8(4), 210-238. Doi:10.1090/cbmath/008/10

Zazkis, R., \& Leikin, R.(2010). Advanced Mathematical Knowledge in Teaching Practice: Perceptions of Secondary Mathematics Teachers. Mathematical Thinking and Learning, 12(4), 263-281. Doi: $10.1080 / 10986061003786349$ 